\title{
The effect of concentrates on production traits, biochemical parameters and thyroid hormones concentration in Dubrovnik sheep fed forage based-diets
}

\author{
Zvonko Antunović ${ }^{1}$, Ivica Marić2 ${ }^{2}$ Željka Klir ${ }^{1 *}$, Boro Mioč \\ and Josip Novoselec ${ }^{1}$
}

${ }^{1}$ Faculty of Agrobiotechnical Sciences Osijek, J. J. Strossmayer University of Osijek, Osijek, Croatia

${ }^{2}$ Croatian Agricultural Agency, Zagreb, Croatia

${ }^{3}$ Department of Animal Science and Technology, Faculty of Agriculture, University of Zagreb, Zagreb, Croatia

\begin{abstract}
ANTUNOVIĆ, Z., I. MARIĆ, Ž. KLIR, B. MIOČ, J. NOVOSELEC: The effect of concentrates on production traits, biochemical parameters and thyroid hormones concentration in Dubrovnik sheep fed forage based-diets. Vet. arhiv 89, 505-518, 2019.
\end{abstract}

\begin{abstract}
The research was carried out on 20 Dubrovnik sheep, divided into two groups. During the day, ewes and lambs were out in pasture and in the evening, after returning to the barn, ewes of group I were fed with only hay, and group II, besides hay, received $200 \mathrm{~g}$ corn and $100 \mathrm{~g}$ wheat bran. Body measurement, assessment of body condition, weighing and blood sampling were carried out in highly pregnant and lactating ewes. The addition of concentrate feed to the ewes' diets was justified because it improved the ewes' production traits (higher body weight, lower ewe weight loss per lamb, better body development indices). The significantly higher concentrations of cholesterol, beta-hydroxybutirate and thyroxine hormone in the blood of group II show that metabolic profile indicators may be considered as a good criterion for assessing their nutritional status. The research showed that the genetic potential of Dubrovnik sheep has not been fully exploited so that improved nutrition may significantly improve the ewes' production traits, which should guarantee the survival of this, the most endangered native Croatian breed of sheep.
\end{abstract}

Key words: Dubrovnik sheep; concentrates; forage; biochemical parameters; thyroid hormones

\section{Introduction}

Recognition, preservation and promotion of specific genotypes from domestic animals for a specific breeding area and country are mandatory for zootechnical, ethical, cultural,

\footnotetext{
${ }^{*}$ Corresponding author:

Željka Klir, PhD, Faculty of Agrobiotechnical Sciences Osijek, J. J. Strossmayer University of Osijek, V. Preloga 1, 31000 Osijek, Croatia, Phone: +385 31554 906, E-mail: zklir@fazos.hr
} 


\section{Z. Antunović et al.: Production traits and blood parameters of Dubrovnik sheep}

scientific and other reasons. Twenty-seven breeds are reared specifically in the Republic of Croatia, including 9 native breeds of sheep. For a long period of time, it has been planned to prevent the reduction of the number of native breeds, including the critically endangered breed of Dubrovnik sheep (761 head). The Dubrovnik sheep is a mediumdeveloped sheep with a well-balanced body, and an average body weight of about $45 \mathrm{~kg}$. The fleece is mostly white, of the semi-closed to closed type. In lactation, lasting 6 to 8 months, the ewes produce approximately $120 \mathrm{~L}$ of milk and 0.8 to $1.4 \mathrm{~kg}$ of wool. One of the best ways to preserve native and protected breeds of domestic animals, including the Dubrovnik sheep, is its use in the production of traditional food of good quality and other products that are increasingly sought after. This will lead to the improvement of its production traits. Studying the production traits of sheep gives us a clearer picture of their genetic potential. The importance of feeding, as the most significant non-genetic factor in sheep breeding, has been highlighted by several authors. Considering the rearing of Dubrovnik sheep in an area with a Mediterranean climate, the importance of feeding and its improvement through the inclusion of different concentrates into diets was studied (MOLLE et al., 1997 and 2008; JOY et al., 2014). These supplementations are necessary because high milk yield and the physical development of lambs depend on it (GALVANI et al., 2014), especially during high pregnancy and lactation (SANTOS et al., 2018). In addition to the usual methods of monitoring the feeding status of sheep, such as monitoring productivity and the index of their physical condition, the metabolic profile of blood is increasingly used as a reliable criterion for assessing the feeding quality and health of sheep (ANTUNOVIĆ et al., 2002; CALDEIRA et al., 2007). The metabolic profile includes monitoring biochemical parameters (minerals, metabolites) and enzyme activity in the blood of animals. These parameters indicate the sheep's energy, protein, and mineral supply, indicating certain nutritional errors. The traditional feeding of Dubrovnik sheep is based on grazing throughout the whole year, supported by the mild Mediterranean climate. During the spring, when the vegetation is lush, the sheep, along with their lambs, tend to graze throughout the day. In the summer months, sheep go to the pasture at early dawn, and at 09:00 am the farmers return them to the barn. In autumn and winter, due to the mild climate, vegetation is recovered and sheep graze throughout the whole day. The sheep's diet is supplemented with hay, and only a small number of farmers have recently begun to offer their sheep concentrated feedstuffs (mainly corn and wheat bran). Thus, this research aimed to determine the production traits, biochemical parameters and thyroid hormone concentrations of Dubrovnik sheep fed in the traditional way and on diets containing concentrates.

\section{Materials and methods}

Experimental design and body measurements. The study was carried out on 20 Dubrovnik sheep in the Dubrovnik-Neretva County. The family farm in question is 
located at about $135 \mathrm{~m}$ above sea level, where a Mediterranean climate predominates. The ewes were divided into two groups of 10 highly pregnant animals (the last 4 weeks of pregnancy), with an average age of 4 years, all healthy and in good condition. The division of the ewes into groups was done after ultrasound determination of the length of pregnancy (approximately day 90; standard ultrasound device: Tringa 300, PIE Medical, Netherlands) and body weight (44.00 $\mathrm{kg} \pm 4.15)$.

During the research in ewes during late pregnancy and early lactation (day 7 of lactation), body measurements, and body weight were determined, body condition was assessed and a blood sample was taken. The body measurements of the ewes were taken with a Lydtin's stick and a cattle measuring tape (height at withers, height at rump, body length, heart girth, chest width, chest depth, width of pelvis, pelvis length, circumference of cannon bone) while body weight was measured by electronic weighing. The body condition scores (BCS) of the ewes $(1=$ emaciated to $5=$ obese $)$ was evaluated by two trained technicians according to RUSSEL (1991). The index of anamorphosys and body proportions were determined according to CHIOFALO et al. (2004), and indices of body compactness and muscularity according to ĆINKULOV et al. (2003).

The Committee for Animal Welfare of the Faculty of Agriculture in Osijek established that the present research was being carried out pursuant to the legal provisions of the Animal Protection Act (Official Gazette No. 133/2006, 37/2013 and No. 125/2013).

Feeding and feed mixture analysis. Both groups of ewes stayed on pasture throughout the whole day, and in the evening, after returning to the barn, they were offered only hay ad libitum (group I), or hay and $200 \mathrm{~g}$ of corn and $100 \mathrm{~g}$ of wheat bran per head per day (group II). Grazing was carried out in the traditional way. In spring, ewes grazed throughout the day along with their lambs, while in the summer the ewes grazed from early dawn to 09:00 am, when they returned to the barn. The ewes in group I did not receive concentrated feed in their diets, while group II received a limited amount of corn $(200 \mathrm{~g})$ and wheat bran $(100 \mathrm{~g})$ per head. The chemical composition of the feedstuffs used for ewes and lambs is shown in Table 1.

During vegetation, sampling of green forage samples was carried out for five periods every 30 days in four replicates, while the results of the analysis were presented as one representative sample. The crude protein content of the feed samples was determined by the Kjeldahl method (PEARSON, 1976), while ether extract was determined according to the method described by ONWUKA (2005). The crude fiber content was determined 
by the Weende method (OFFOR et al., 2014). The digestible and metabolizable energy of the feed for ewes and lambs was estimated according to DLG (1993).

Table 1. Chemical composition of green forage, hay and concentrated feedstuffs in the diets of ewes and lambs

\begin{tabular}{|l|c|c|c|c|}
\hline \multirow{2}{*}{ Parameters (\% DM) } & \multicolumn{4}{|c|}{ Feedstuffs } \\
\cline { 2 - 5 } & Green forage & Hay & Corn & Wheat bran \\
\hline Dry matter & 22.70 & 91.13 & 87.02 & 87.07 \\
\hline Crude proteins & 16.08 & 16.24 & 7.80 & 14.63 \\
\hline Crude fiber & 25.20 & 35.56 & 2.44 & 9.65 \\
\hline Crude ash & 9.46 & 7.49 & 1.09 & 4.45 \\
\hline Crude fat & 3.54 & 2.32 & 3.02 & 1.18 \\
\hline NET & 37.65 & 29.52 & 72.67 & 57.16 \\
\hline Digestible energy, MJ kg-1 DM & 2.31 & 8.65 & 14.77 & 11.16 \\
\hline Metabolizable energy, MJ kg-1 DM & 1.87 & 7.09 & 12.11 & 9.15 \\
\hline
\end{tabular}

DM-dry matter, NET-net energy for lactation.

Blood sample collection and parameters analyzed. Blood samples for biochemical analysis, enzyme activity, and determination of the thyroid gland hormones were taken from the jugular vein in the morning, before the ewes left the barn and started grazing, into sterile vacuum tubes (Venoject ${ }^{\circledR}$, Sterile Terumo Europe, Leuven, Belgium). Thereafter, the samples were centrifuged for 10 minutes at $3000 \mathrm{rpm}$ for serum separation, and subsequently frozen. Biochemical parameters, mineral and metabolite concentrations, and enzyme activity were determined with Olympus System Reagents, manufactured and distributed by Olympus Diagnostic GmbH (Irish Branch), Lismeehan, Ireland, manufactured for Olympus Diagnostic GmbH, Hamburg, using an OLYMPUS AU 400. Concentrations of total triiodothyronine (T3) and thyroxine (T4) in blood serum were determined by means of duplicate determinations using commercial kits for clinical use in humans (Abbott Laboratories, USA) by Imx-Abbott immunoanalyzer. The methods used for determination of T3 and T4 were MEIA (Microparticle Enzyme Immunoassay) and FPAI (Fluorescence Polarization Immunoassay). Sensitivity of the assay was less than $0.4 \mathrm{nmol} \mathrm{L}^{-1}$ (T3) and $12.8 \mathrm{nmol} \mathrm{L}^{-1}$ (T4). Mean recovery rates were $98.6 \%$. The ratio between the T3 / T4 was determined by dividing these two values for each animal separately. The animals used in this study were maintained in facilities approved by the Croatian Association for Accreditation of Laboratory Animal Care, and in accordance with the current regulations and standards issued by the Croatian Ministry of Agriculture, Forestry and Water Management.

Statistical analysis. The results were analyzed with ANOVA in Statistica (Stat Soft, Inc. 2017) with the fixed effect of feeding and reproduction status. The results 


\section{Z. Antunović et al.: Production traits and blood parameters of Dubrovnik sheep}

were expressed as the arithmetic mean value (mean). Differences between groups were considered significant at the level of $\mathrm{P}<0.05$.

\section{Results}

It is evident that the addition of concentrate feed to the diets of ewes in late pregnancy $(\mathrm{P}<0.05)$ and ewes in lactation $(\mathrm{P}<0.01)$ in experimental group II resulted in significantly higher body weight and body proportion index, in comparison with sheep from group I (Table 2). Significantly lower $(\mathrm{P}<0.05)$ loss of body weight in the sheep in group II was also found compared to group I. Although the higher birth weight of lambs from group II was established compared to group I, there was no significant differences $(\mathrm{P}>0.05)$. When comparing the body weight of highly pregnant ewes and ewes in lactation within the groups, the significant effect $(\mathrm{P}<0.01)$ of reproductive status is evident. In both groups, as expected, the body weight of highly pregnant ewes was significantly higher in comparison to ewes in lactation. There was also a significantly higher body proportion index in highly pregnant ewes compared to ewes in lactation in both groups. In ewes of group II compared to group I, better body condition score indices were established, but the differences were not significant $(\mathrm{P}>0.05)$.

Table 2. Production traits and body development indices of Dubrovnik sheep and birth weight of lambs

\begin{tabular}{|c|c|c|c|c|c|c|c|c|}
\hline \multirow[b]{3}{*}{ Parameters } & \multicolumn{4}{|c|}{ Groups (mean) } & \multicolumn{4}{|c|}{ Effect (p-value) } \\
\hline & \multicolumn{2}{|c|}{ Pasture $(\mathrm{P})$} & \multicolumn{2}{|c|}{ Concentrates $(\mathrm{C})$} & \multicolumn{2}{|c|}{ Diet } & \multicolumn{2}{|c|}{$\begin{array}{l}\text { Reproduction } \\
\text { status }\end{array}$} \\
\hline & LP & $\mathrm{L}-7$ & LP & L-7 & LP & L-7 & $\mathrm{P}$ & $\mathrm{C}$ \\
\hline $\mathrm{BW}, \mathrm{kg}$ & 50.32 & 44.22 & 54.56 & 50.17 & 0.02 & $<0.001$ & $<0.001$ & 0.006 \\
\hline BW loss*, kg & \multicolumn{2}{|c|}{6.10} & \multicolumn{2}{|c|}{4.39} & \multicolumn{2}{|c|}{0.04} & \multicolumn{2}{|c|}{ 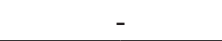 } \\
\hline $\begin{array}{l}\text { Birth weight } \\
\text { of lambs, kg }\end{array}$ & \multicolumn{2}{|c|}{3.49} & \multicolumn{2}{|c|}{3.87} & \multicolumn{2}{|c|}{0.22} & \multicolumn{2}{|c|}{-} \\
\hline \multicolumn{9}{|c|}{ Indices of body development } \\
\hline IA & 118.37 & 109.92 & 118.30 & 114.55 & 0.97 & 0.43 & 0.18 & 0.31 \\
\hline IBP & 78.23 & 68.74 & 83.75 & 77.03 & 0.04 & $<0.001$ & $<0.001$ & 0.001 \\
\hline $\mathrm{BCS}$ & 2.90 & 2.76 & 3.15 & 3.03 & 0.62 & 0.09 & 0.63 & 0.32 \\
\hline IBC & 133.52 & 128.28 & 133.48 & 131.53 & 0.42 & 0.27 & 0.19 & 0.55 \\
\hline
\end{tabular}

*From late pregnancy to day 7 of lactation; BW - body weight; LP - late pregnancy, L-7 - $7^{\text {th }}$ day of lactation; IA - Index of anamorphosis, IBP - Index of body proportions, BCS - body condition score, IBC - Index of body compactness

From analysis of Table 3 it is evident that there were no significant differences in the concentration of minerals in the ewes' blood in relation to diet. In the blood of highly pregnant ewes in both groups there were significantly higher concentrations of $\mathrm{Na}$ 
and $\mathrm{Cl}$, and in group II significantly higher concentrations of $\mathrm{Ca}$ were determined. The effect of the ewes' feed led to significantly higher concentrations of total cholesterol and BHB in the blood of ewes in late pregnancy and lactation, as well as LDL-cholesterol in highly pregnant ewes in group I compared to group II. Also, the significant influence of reproductive status on concentration of urea, glucose, HDL- and LDL-cholesterol, triglyceride and creatinine in ewes' blood of group I and total proteins, total cholesterol, HDL- and LDL-cholesterol, triglyceride and creatinine in the ewes' blood in group II was determined.

Table 3. Concentration of biochemical parameters in the blood of Dubrovnik sheep

\begin{tabular}{|l|c|c|c|c|c|c|c|c|}
\hline \multirow{2}{*}{} & \multicolumn{4}{|c|}{ Group (mean) } & \multicolumn{3}{c|}{ Effect (P-value) } \\
\cline { 2 - 10 } & \multicolumn{2}{|c|}{ Pasture (P) } & \multicolumn{2}{|c|}{ Concentrates (C) } & \multicolumn{2}{c|}{ Diet } & \multicolumn{2}{c|}{$\begin{array}{c}\text { Reproduction } \\
\text { status }\end{array}$} \\
\cline { 2 - 10 } mmol L $^{-1}$ & LP & L-7 & LP & L-7 & LP & L-7 & P & C \\
\hline Ca & 2.98 & 2.20 & 3.01 & 2.28 & 0.70 & 0.89 & 0.07 & $<0.001$ \\
\hline P-inorganic & 1.40 & 1.37 & 1.94 & 1.76 & 0.18 & 0.21 & 0.77 & 0.75 \\
\hline K & 5.17 & 4.98 & 5.50 & 5.30 & 0.25 & 0.37 & 0.43 & 0.62 \\
\hline Na & 173.39 & 160.60 & 177.14 & 161.75 & 0.18 & 0.51 & $<0.001$ & $<0.001$ \\
\hline Cl & 127.14 & 117.80 & 131.14 & 114.00 & 0.29 & 0.20 & 0.02 & 0.003 \\
\hline Fe, $\mu$ mol L-1 & 23.16 & 24.70 & 26.62 & 27.45 & 0.33 & 0.34 & 0.51 & 0.86 \\
\hline Urea & 5.04 & 7.78 & 6.10 & 6.03 & 0.13 & 0.12 & 0.002 & 0.94 \\
\hline Glucose & 2.93 & 2.36 & 3.08 & 2.90 & 0.48 & 0.13 & 0.03 & 0.56 \\
\hline TP, g L & 78.89 & 75.26 & 85.40 & 75.00 & 0.06 & 0.95 & 0.28 & 0.04 \\
\hline Albumin, g L-1 & 32.10 & 31.92 & 32.99 & 31.43 & 0.22 & 0.73 & 0.79 & 0.24 \\
\hline Globulin, g L-1 & 46.79 & 43.34 & 52.42 & 43.58 & 0.07 & 0.96 & 0.23 & 0.03 \\
\hline CHOL & 2.32 & 2.00 & 1.97 & 1.48 & 0.02 & 0.03 & 0.17 & 0.001 \\
\hline HDL & 1.48 & 0.94 & 1.41 & 0.83 & 0.39 & 0.70 & 0.03 & $<0.001$ \\
\hline LDL & 0.65 & 1.01 & 0.36 & 0.60 & 0.007 & 0.08 & 0.04 & 0.02 \\
\hline TGC & 0.41 & 0.12 & 0.40 & 0.10 & 0.28 & 0.41 & $<0.001$ & $<0.001$ \\
\hline $\begin{array}{l}\text { Bilirubin } \\
\mu \text { mmol L-1 }\end{array}$ & 2.61 & 3.20 & 3.20 & 3.00 & 0.36 & 0.41 & 0.34 & 0.72 \\
\hline NEFA & 0.43 & 0.50 & 0.35 & 0.40 & 0.29 & 0.20 & 0.42 & 0.64 \\
\hline BHB & 0.92 & 1.05 & 0.59 & 0.71 & 0.04 & 0.04 & 0.06 & 0.37 \\
\hline
\end{tabular}

LP - late pregnancy, L-7 - day 7 during lactation; TP - total proteins, CHOL - total cholesterol, HDL - high density lipoprotein, LDL - low density lipoprotein, TGC - triglycerides, NEFA - non-esterified fatty acids, BHB - beta-hydroxybutyrate. 


\section{Z. Antunović et al.: Production traits and blood parameters of Dubrovnik sheep}

Table 4. Activity of enzymes and concentration of thyroid hormones in the blood of Dubrovnik sheep

\begin{tabular}{|c|c|c|c|c|c|c|c|c|}
\hline \multirow[b]{3}{*}{ Parameter } & \multicolumn{4}{|c|}{ Group (mean) } & \multicolumn{4}{|c|}{ Effect (P-value) } \\
\hline & \multicolumn{2}{|c|}{ Pasture (P) } & \multicolumn{2}{|c|}{ Concentrates (C) } & \multicolumn{2}{|c|}{ Diet } & \multicolumn{2}{|c|}{ Reproduction status } \\
\hline & LP & L-7 & LP & L-7 & LP & L-7 & $\mathrm{P}$ & $\mathrm{C}$ \\
\hline AST U L-1 & 96.00 & 80.00 & 98.14 & 69.75 & 0.75 & 0.29 & 0.06 & 0.006 \\
\hline ALT U L L-1 & 18.00 & 9.60 & 20.71 & 11.25 & 0.21 & 0.12 & 0.002 & $<0.001$ \\
\hline ALP U L ${ }^{-1}$ & 130.71 & 123.40 & 170.43 & 94.00 & 0.34 & 0.59 & 0.88 & 0.09 \\
\hline GGT U L ${ }^{-1}$ & 52.61 & 77.60 & 57.81 & 61.75 & 0.52 & 0.002 & 0.06 & 0.14 \\
\hline $\mathrm{LDH} \mathrm{U} \mathrm{L}^{-1}$ & 361.14 & 387.24 & 373.57 & 392.45 & 0.82 & 0.87 & 0.63 & 0.59 \\
\hline $\mathrm{T}_{3}, \mu \mathrm{mol} \mathrm{L}-1$ & 1.10 & 1.63 & 1.09 & 1.54 & 0.93 & 0.77 & 0.002 & 0.07 \\
\hline $\mathrm{T}_{4}, \mu \mathrm{mol} \mathrm{L}-1$ & 68.42 & 77.42 & 91.74 & 96.14 & 0.008 & 0.048 & 0.32 & 0.66 \\
\hline $\mathrm{T}_{3} / \mathrm{T}_{4}$ & 0.02 & 0.022 & 0.01 & 0.016 & 0.005 & 0.14 & 0.045 & 0.07 \\
\hline
\end{tabular}

LP-late pregnancy, L-7 - day 7 during lactation; AST - aspartate-aminotransferase, ALT - alanine aminotransferase, ALP - alkaline phosphatase, GGT - gamma-glutamyl transferase, LDH - lactate dehydrogenase.

From the analysis of the activity of enzymes in the blood of ewes from group II in lactation, only significantly higher GGT activity was determined (Table 4). Significantly higher activity of AST and ALT was observed in highly pregnant ewes compared to ewes in lactation in both groups. Also, the significant effect of feed on the concentrations of thyroid hormones was also determined. In group II, a significantly higher concentration of T4 was found in relation to group I and in highly pregnant ewes and ewes in lactation. In the blood of highly pregnant ewes of group I, a significantly lower T3 concentration and $\mathrm{T} 3$ / T4 ratio were found in relation to ewes in lactation.

\section{Discussion}

The improvements found in the productive traits and indices of body development of ewes indicate the justification of adding concentrated feed (corn and wheat bran) to the diet of Dubrovnik sheep, especially in demanding production stages (late pregnancy and early lactation). In both groups, the body weight of highlyy pregnant ewes was significantly higher in comparison to ewes in lactation as was expected. When ewes are fed properly during pregnancy, their body weight increases by about $20 \%$. ANTUNOVIĆ et al. (2003) found loss of body weight of $7.72 \mathrm{~kg}$ in Merinolandschaf sheep after lambing during the winter season, and of $6.64 \mathrm{~kg}$ during summer. A similar loss of ewes' body weight (6.3 kg) after lambing a single lamb was found by ORR and TREACHER (1989). McDONALD et al. (2002) highlighted the significant influence of energy intake in the last six weeks of pregnancy in ewes, on the changes in body weight of the ewe and the lamb. 


\section{Z. Antunović et al.: Production traits and blood parameters of Dubrovnik sheep}

In the research by MOLLE et al. (1997), when lactating sheep are fed with pasture and the addition of corn grains, positive effects on body weight and physical condition of sheep were determined. RIPOLL-BOSCH et al. (2014) did not determine significant changes in the lambs' birth weight from feeding ewes with $300 \mathrm{~g}$ of concentrates in the pre partum period. A limited supply of nutrients to the fetus is one of the most important reasons for its lower development at birth (WALLACE et al., 2005) and postnatal growth (McGOVERN et al., 2015). In the research by SANTOS et al. (2018) concentrates used in diets increased the average daily gain of lambs.

Analyzing the biochemical parameters in the blood of Dubrovnik sheep, it was found that there were no significant differences in mineral concentrations related to feeding. However, higher concentrations of inorganic phosphorus $(\mathrm{P})$ were found in group II when

compared to group I, indicating that concentrate feed is rich in P. UNDERWOOD and SUTTLE (2001) reported that concentrates contain a large concentration of P. It is known that the P concentration in blood is dependent on its content in in the diet (JAIN and CHOPRA, 1998). Corn has a very low concentration of Ca (about $2 \mathrm{~g} \mathrm{~kg}^{-1}$ ) and a high concentration of $\mathrm{P}$ (2.5 to $3 \mathrm{~g} \mathrm{~kg}^{-1}$; BLAIR, 2011). In the blood of highly pregnant ewes in both groups, significantly higher concentrations of $\mathrm{Na}$ and $\mathrm{Cl}$ were determined, and in group II a significantly higher concentration of $\mathrm{Ca}$, which indicates the loaded metabolism in highly pregnant ewes. The fall in Ca concentrations in ruminant blood in lactation may be associated with the risk of hypocalcaemia at birth (KANEKO et al., 2008).

These changes may be related to metabolic disorders caused by late pregnancy, which may lead to significant deviations in blood metabolites concentrations (ANTUNOVIĆ et al., 2002). Pregnancy is a physiological condition when the organism of a pregnant animal is the only Ca source necessary for mineralization of the fetal skeleton. During lactation, large concentrations of $\mathrm{Ca}$ are excreted in the milk, thus hypocalcaemia occurs, especially when the diet does not have enough $\mathrm{Ca}$, although occurrence of hypocalcaemia is not common in sheep (TREACHER and CAJA, 2002). When comparing mineral concentrations with the reference values for sheep (KANEKO et al., 2008), lower concentrations of $\mathrm{Ca}$, and higher $\mathrm{Na}, \mathrm{Cl}$ and $\mathrm{K}$ concentrations were found, at the upper limit of the reference values. This may be related to the quality of the diet. This is especially important for $\mathrm{Na}$ and $\mathrm{Cl}$ concentrations. The reason for the higher concentrations in the blood may be due to grazing on pastures where the wind from the sea causes the spread of salt and an increase in these minerals (ANTUNOVIĆ et al., 2011). Concentrations of $\mathrm{K}$ indicate the abundance of $\mathrm{K}$ in the green forage from pasture.

The glucose concentration was slightly higher, although at the lower limit of the reference values in ewes in group II fed with the addition of concentrates, but the differences were not significant $(\mathrm{P}>0.05)$. These changes may be related to the quality of the diet of this group. The starch from the corn is digested significantly more slowly in the rumen 
than starch from other cereals, and when the content of corn in the diet is high, starch is directed to the small intestine where it is absorbed as glucose (BLAIR, 2011). In the blood of highly pregnant ewes and ewes in lactation of the Tsigai breed, ANTUNOVIĆ et al. (2011) found similar changes in urea, total protein, albumin, cholesterol and triglyceride concentrations. A decrease in concentrations of total protein in the blood of ewes in lactation can be associated with the significant extraction of globulin from the plasma during the production of colostrum in the mammary glands (KANEKO et al., 2008). The decrease in glucose concentration during lactation may be associated with enhanced milk synthesis when glucose is mobilized for lactose production (McNEILL et al., 1998). The concentrations of glucose, NEFA and BHB indicate a negative energy balance in ewes on pasture compared to those fed with the addition of concentrates. Similar observations were made by ANNICCHIARICO et al. (2007) in lactating ewes grazing Mediterranean pastures, and in those fed with the addition of concentrated feed (corn, barley and peas) during the summer. The higher blood cholesterol concentrations in both groups compared to the reference values (KANEKO et al., 2008) suggest a difference in the fatty acid composition of the diets (DALEY et al., 2010). Blood urea concentrations may be a good indicator of the amount of nitrogen intake from the feed, although not the energy available in the rumen for the microorganisms' requirements (KOHN et al., 2005). NAZIFI et al. (2002) also found a significant decrease in triglyceride concentrations in the blood of lactating ewes between the second and fourth week after the birth.

If an animal is unable to consume enough feed to meet its maintenance requirements, it uses body reserves, which results in an increase of serum NEFA and urea due to adipose and protein catabolism (CALDEIRA et al., 2007). Concentrations of NEFA higher than $0.40 \mathrm{mmol} \mathrm{L}^{-1}$ indicate problems with energy balance and subsequent intensive lipomobilization (OETZEL, 2004). This is particularly expressed because these sheep were in the last third of pregnancy and early lactation, when nutritional needs are increased. DUFFIELD (2000) found that determining concentrations of NEFA in the blood is most often used for checking the body energy imbalance of pre partum animals, while in the postpartum period BHB concentrations are used. Stress has been shown to induce energy mobilization in the form of lipid catabolism and protein degradation (RICHARDSON and HERD, 2004). The fact is that pregnancy, especially late pregnancy and early lactation, are very stressful periods for sheep. Mobilization of fat reserves is indicated by elevated plasma concentrations of NEFA and BHBA (ROBINSON et al., 2002). Concentrations of BHB less than $0.8 \mathrm{mmol} \mathrm{L}^{-1}$ constitute an adequate level of feeding (RUSSEL, 1984), however concentrations greater than $1.0 \mathrm{mmol} \mathrm{L}^{-1}$ are deemed high, and indicate fat mobilization (MORGANTE, 2004).

By comparing the activity of the enzymes in the blood from both groups of ewes with reference values for sheep, KANEKO et al. (2008) found that they were within the physiological limits, apart from minor changes in GGT activity. This indicates a 


\section{Z. Antunović et al.: Production traits and blood parameters of Dubrovnik sheep}

significant burden on the body and an increase in liver metabolism. KANEKO et al. (2008) reported that there were enough GGTs in the ewes' colostrum and the antibodies are transported in the plasma through the neonatal intestinal wall. Increased GGT activity may indicate moderate oxidative stress associated with enhanced glutathione degradation, which is a highly effective non-enzymatic antioxidant molecule (LEE et al., 2005). Changes in the activity of the thyroid hormone in the blood of ewes fed with concentrates indicating a diet rich in energy. TODINI (2007) highlighted that thyroid gland hormone concentrations can be considered as a reliable criterion for assessing animal energy supply. Similar concentrations of thyroid hormone concentrations in Dubrovnik sheep ewes' blood, grazing on pastures and of those fed with the addition of concentrates and meadow hay were determined by ANTUNOVIĆ et al. (2009) and in Tsigai growing lambs (ANTUNOVIĆ et al., 2010).

\section{Conclusions}

On the basis of the results of the present study, it is evident that the traditional way of feeding Dubrovnik sheep is insufficient, since the production traits of ewes fed diets with addition of concentrate feed were improved. This indicates that the genetic potential of Dubrovnik sheep has not been sufficiently exploited. Therefore, the mandatory addition of concentrated feed to ewes' diets is recommended, especially in demanding production stages such as pregnancy and early lactation. Similar research with a larger number of extensively kept sheep breeds is worthy of further study.

\section{Acknowledgements}

The study was carried out within a project financed by the Ministry of Science, Education and Sports of the Republic of Croatia (079-1780469-0225).

\section{References}

ANNICCHIARCIO, G., S. CLAPS, R. MARINO, G. TERZANO, G. CATERNOLO, L. TAIBI (2007): Effect of the concentrate source on milk yield, milk composition and feeding behavior of grazing sheep during summer season. Options Mediterraneennes 74, 345-350.

ANTUNOVIĆ, Z., Đ. SENČIĆ, M. ŠPERANDA, B. LIKER (2002): Influence of the season and the reproductive status of ewes on blood parameters. Small Ruminant Res. 45, 39-44.

DOI: 10.1016/S0921-4488(02)00109-8

ANTUNOVIĆ, Z., Z. STEINER, Đ. SENČIĆ, M. DOMAĆINOVIĆ, Z. STEINER (2003): Effect of feeding season and reproductive traits of ewes and suckling lambs. Poljoprivreda 9, 62-68.

ANTUNOVIĆ, Z., I. MARIĆ, I. MATANIĆ, Đ. SENČIĆ, M. ŠPERANDA, J. NOVOSELEC (2009): Blood enzymes and thyroid hormones activity for assessment of selenium supply in sheep. Krmiva. 51, 131-137. 
ANTUNOVIĆ, Z., J. NOVOSELEC, H. SAUERWEIN, M. VEGARA, M., ŠPERANDA (2010): Blood metabolic hormones and leptin in growing lambs. Poljoprivreda 16, 29-34.

ANTUNOVIĆ, Z., I. MARIĆ, Z. STEINER, M. VEGARA, J. NOVOSELAC (2011): Blood metabolic profile of the Dubrovnik sheep - Croatian endangered breed. Maced. J. Anim. Sci. $1,35-38$.

BLAIR, R. (2011): Nutrition and feeding of organic cattle, CABI, Canada, p. 293.

CALDEIRA, R. M., A. T. BELO, C. C. SANTOS, M. I. VAZQUEZ, A. V. PORTUGAL (2007): The effect of long term feed restriction and over-nutrition on body condition score, blood metabolites and hormonal profiles in ewes. Small Ruminant Res. 68, 242-255.

DOI: 10.1016/j.smallrumres.2005.08.026

CHIOFALO, V., L. LIOTTA, B. CHIOFALO (2004): Effect of the administration of Lactobacilli on body growth and on the metabolic profile in growing Maltese goat kids. Reprod. Nutr. Dev. 44, 449-457.

ĆINKULOV, M., M. KRAJINOVIĆ, I. PIHLER (2003): Phenotypic differences between two types of Tsigai breed of sheep. Lucrai stiintifice Zootehnie si Biotehnologii, XXXVI, 1-6.

DALEY, C. A., A. ABBOTT, P. S. DOYLE, G. A. NADER, S. LARSON (2010): A review of fatty acid profiles and antioxidant content in grass-fed and grain-fed beef. Nutr. J. 9, 10.

DOI: 10.1186/1475-2891-9-10.

DLG (1993): Feed value tables for ruminants, 6 Auflage, Frankfurt am Main. (in German)

DUFFIELD, T. F. (2000): Subclinical ketosis in lactating dairy cattle. Vet. Clin. N. Am. Food. A. $16,231-252$.

DOI: $10.1016 / \mathrm{S} 0749-0720(15) 30103-1$

GALVANI, D. B., C. C. PIRES, C. H. HÜBNER, S. CARVALHO, T. P. WOMMER (2014): Growth performance and carcass traits of early-weaned lambs as affected by the nutritional regimen of lactating ewes. Small Ruminant Res. 120, 1-5.

DOI: 10.1016/j.smallrumres.2014.03.008

JAIN, R. K., R. C. CHOPRA (1998): Influence of dietary phosphorus in adequacy on concentration of inorganic phosphorus, calcium, magnesium in plasma, saliva and rumen liquor in calves. Indian J. Anim. Nutr. 15, 83-88.

JOY, M., R. RIPOLL-BOSCH, A. SANZ, F. MOLINO, I. BLASCO, J. ALAVAREZ-RODRIGUEZ (2014): Effects of concentrate supplementation on forage intake, metabolic profile and milk fatty acid composition of unselected ewes raising lambs. Anim. Feed Sci. Tech. 187, 19-29. DOI: 10.1016/j.anifeedsci.2013.09.014

KANEKO, J. J., HARVEY, M. L. BRUSS (2008): Clinical Biochemistry of Domestic Animals, Elsevier/Academic Press, Amsterdam, Netherlands, p. 932.

KOHN, R. A., M. M. DINNEEN, E. RUSSEK-COHEN (2005): Using blood urea nitrogen to predict nitrogen excretion and efficiency of nitrogen utilization in cattle, sheep, goats, horses, pigs and rats. J. Anim. Sci. 83, 879-889.

DOI: $10.2527 / 2005.834879 x$

Vet. arhiv 89 (4), 505-518, 2019 


\section{Z. Antunović et al.: Production traits and blood parameters of Dubrovnik sheep}

LEE, D. H., J. S. LIM, J. H. YANG, M. H HA, D. R., JACOBS (2005): Serum gammaglutamyltransferase with in its normal range predicts a chronic elevation of alanine aminotransferase: A Four Year Follow- up Study. Free Radical Res. 39, 589-593.

McDONALD, P., R. A. EDWARDS, J. F. D. GREENHALGH, C. D. MORGAN (2002): Animal nutrition, Pearson Education Limited, Edinburgh, Scotland, p. 693.

McGOVERN, F. M., F. P. CAMPION, S. LOTT, T. M. BOLAND (2015): Altering ewe nutrition in late gestation: I. The impact on pre- and postpartum ewe performance. J. Anim. Sci. 93, 4860-4872.

DOI: $10.2527 /$ jas.2015-9019.

McNEILL, D. M., P. M. MURPHY, D. R. LIDSAY (1998): Blood lactose v. milk lactose as a monitor of lactogenesis and colostrum production in Merino ewes. Aust. J. Agric. Res. 49, 581-587.

MOLLE, G., S. LIGIOS, N. FOIS, M. DECANDIA, S. CASAU, G. BOMBOI (1997): Response by dairy ewes to different sward heights under continuous stocking either unsupplemented or supplemented with corn grain, in: Proceedings of the FAO-CIHEAM-E.C. Meeting on Sheep and Goat Nutrition, 1996, Options Mediterranneennes, Serie A. 34, 65-70.

MOLLE, G., M. DECANDIA, A. CABIDDU, S. Y. LANDAU, A. CANNAS (2008): An update on the nutrition of dairy sheep grazing Mediterranean pastures. Small Ruminant Res. 77, 93-112. DOI: $10.1016 /$ j.smallrumres.2008.03.003

MORGANTE, M. (2004): Digestive disturbance and metabolic-nutritional disorders. In: Dairy sheep nutrition. CAB International, Wallingford, United Kingdom, pp. 165-190.

NAZIFI, S., M. SAEB, S. M. GHAVAMI (2002): Serum lipid profile in Iranian fat- tailed sheep in late pregnancy, at parturition and during the post-parturition period. J. Vet. Med. Series A. 49, 9-12.

OETZEL, G. R. (2004): Monitoring and testing dairy herds for metabolic disease. Vet. Clin. North Am. Food Anim. Parct. 20, 651-674.

DOI: $10.1016 /$ j.cvfa.2004.06.006

OFFOR, I. F., R. C. EHIRI, C. N. NJOKU (2014): Proximate nutritional analysis and heavy metal composition of dried Moringa Oleifera leaves from Oshiri Onicha L.G.A, Ebonyi State, Nigeria. J. Environ. Sci. Tox. Food Technol. 8, 57-62.

DOI: $10.9790 / 2402-08115762$

ONWUKA, G. I. (2005): Food Analysis and Instrumentation: Theory and Practice. Naphthali Prints, Lagos, Nigeria.

ORR, R. J., T. T. TREACHER (1989): The effect of concentrate level on the intake of grass silages by ewes in late pregnancy. Animal Prod. 48, 109-120.

DOI: $10.1017 / \mathrm{S} 0003356100003846$

PEARSON, D. A. (1976): The Chemical analysis of foods. Churchill Livingstone, Edinburg, Scotland, pp. 6-25. 
RICHARDSON, E. C., R. M. HERD (2004): Biological basis for variation in residual feed intake in beef cattle. 2. Synthesis of results following divergent selection. Austr. J. Exp. Agric. 44: 431-440, doi: 10.1071/EA02221.

RIPOLL-BOSCH, R., M. JOY, A. SANZ, I. BLASCO, G. RIPOLLI, J. ALVAREZ-RODRIGUEZ (2014): Effect of concentrate supplementation and prolificacy on the productive and economic performance of autochthonous sheep breeds fed forage-based diets. Span. J. Agric. Res. 12, 1099-1104.

DOI: $10.5424 /$ sjar/2014124-6321

ROBINSON, J. J., J. A. ROOKE, T. G. McEVOY (2002): Nutrition for conception and pregnancy. In: Sheep nutrition, CAB International, Wallingford, United Kingdom, 189-211.

RUSSEL, A. (1984): Means of assessing the adequacy of nutrition of pregnant ewes. Livest. Prod. Sci., 11, 429-436. Body condition scoring of sheep. In: Sheep and goat practice. Bailliere Tindall, Philadelphia, USA.

RUSSEL, A. (1991): Body condition scoring of sheep. In: Sheep and goat practice. Bailliere Tindall, Philadelphia, USA, p. 3.

SANTOS, S. K., M. K. FALBO, I. E. SANDINI, F. PACENTCHUK, M. NEUMANN, G. GARBOSSA (2018): Concentrate supplementation strategies in ryegrass pasture for productive performance in lambs. Span. J. Agric. Res. 16, e06SC02.

DOI: $10.5424 /$ sjar/20181614-11067

STATISTICA-Stat Soft Inc., (2017): Version 13.3

TODINI, L. (2007): Thyroid hormones in small ruminants: effects of endogenous, environmental and nutritional factors. Animal. 1, 997-1008.

DOI: $10.1017 / \mathrm{S} 1751731107000262$

TREACHER, T. T., G. CAJA (2002): Nutrition during lactation. In: Sheep nutrition. CABI, Wallingford, United Kingdom, pp. 213-236.

UNDERWOOD, E. J., SUTTLE, N. F. (2001): The mineral nutrition of livestock. CABI, Wallingford, United Kingdom, p. 614.

WALLACE, J. M., T. R. REGNAULT, S. W. LIMESAND, W. W. HAY, JR R. V. ANTHONY (2005): Investigating the causes of low birth weight in contrasting ovine paradigms. J. Physol. $565,19-26$.

DOI: $10.1113 /$ jphysiol.2004.082032

Received: 6 December 2018

Accepted: 9 May 2019

Vet. arhiv 89 (4), 505-518, 2019 


\section{ANTUNOVIĆ, Z., I. MARIĆ, Ž. KLIR, B. MIOČ, J. NOVOSELEC: Utjecaj koncentriranih krmiva na proizvodna svojstva, biokemijske pokazatelje i koncentraciju hormona štitne žlijezde dubrovačke rude hranjene voluminoznim krmivima. Vet. arhiv 89, 505-518, 2019.}

\section{SAŽETAK}

Istraživanje je provedeno na 20 ovaca pasmine dubrovačka ruda, podijeljenih u dvije skupine. Tijekom dana ovce i janjad boravili su na pašnjaku, a navečer, nakon povratka u staju, ovce prve skupine hranjene su samo sijenom, dok su one druge skupine uz sijeno konzumirale $200 \mathrm{~g}$ kukuruza i $100 \mathrm{~g}$ pšeničnih posija. Uzimanje tjelesnih mjera i indeksa tjelesne kondicije, vaganje i uzimanje uzoraka krvi provedeni su u visokogravidnih ovaca i ovaca u laktaciji. Dodatak koncentrirane krme u obroke za ovce opravdan je jer poboljšava proizvodne pokazatelje (veća tjelesna masa, manji gubici tjelesne mase ovaca po janjetu, indeksi tjelesne razvijenosti). Znakovito povećanje koncentracije kolesterola, beta-hidroksibutirata i tiroksina u krvi ovaca druge skupine upućuje na to da se pokazatelji metaboličkog profila mogu uzeti u obzir kao dobar kriterij za utvrđivanje hranidbenog statusa. Istraživanje je pokazalo da genetski potencijal dubrovačke rude nije u potpunosti iskorišten i da poboljšanje hranidbe može znatno poboljšati proizvodne pokazatelje ovaca, što je jamstvo opstanka ove najugroženije izvorne hrvatske pasmine ovaca.

Ključne riječi: dubrovačka ruda; koncentrirana krma; voluminozna krma; biokemijski pokazatelji; hormoni štitne žlijezde 